\title{
LA «OPERACIÓN ROCA». EL FRACASO DE UN PROYECTO LIBERAL EN LA ESPAÑA DE LOS 80
}

\author{
«OPERACIÓN ROCA». \\ THE FAILURE OF A LIBERAL PROJECT IN THE SPAIN OF THE 80s \\ Adrián Magaldi Fernández* \\ Universidad de Cantabria, Santander, España
}

\begin{abstract}
RESUMEN: El hundimiento de Unión de Centro Democrático (UCD) hizo que los diversos sectores que la integraban buscaran un nuevo lugar en el escenario político. Mientras los suaristas trataban de refundar el centro desde el CDS, los democristianos se acercaron a Fraga y los socialdemócratas se integraron en el PSOE. Los grandes huérfanos que dejó la desaparición de UCD fueron los liberales. Este grupo intentó buscar su nuevo lugar, en un primer momento, en torno a Antonio Garrigues Walker, quien lo intentó sin éxito a través del Partido Demócrata Liberal (PDL). Finalmente fue la llamada Operación Roca la que capitalizó dichos intentos. Así nacía el Partido Reformista Democrático (PRD) en torno a la figura del político catalán, con el propósito de formar un partido liberal-demócrata que fuera clave en la política española. El proyecto generó un amplio interés en numerosos sectores de la sociedad, que no tardaron en verse frustrados después del fracaso del PRD en las elecciones de 1986. Este artículo pretende analizar la historia de este proyecto político para comprender las razones de su fracaso.
\end{abstract}

PALABRAS CLAVE: liberalismo, Antonio Garrigues Walker, Miquel Roca, Partido Demócrata Liberal, Partido Reformista Democrático.

ABSTRACT: The collapse of Union of Democratic Center (UCD) made the various sectors that were part of it seek a new place in the political stage. While the suarists tried to refound the center from the CDS, the Christian-Democrats approached Fraga and the Social-Democrats joined the PSOE. The great orphans left by the disappearance of UCD were the Liberals. This group tried to find its new place, at first, around Antonio Garrigues Walker, who tried it unsuccessfully through the Liberal Democratic Party (PDL). At the end, it was the called Operation Roca, which capitalized on these attempts. Thus, the Democratic Reformist Party (PRD) was born around the figure of the Catalan politician, with the purpose of forming a liberal-democratic party that would be key in Spanish politics. The project generated broad interest in numerous sectors of society, which soon became frustrated after the failure of the PRD in the 1986 elections. This article aims to analyze the history of this political project to understand the reasons for its failure.

KEYWORDS: liberalism, Antonio Garrigues Walker, Miquel Roca, Liberal Democratic Party, Democratic Reformist Party.

* Correpondencia a: Adrián Magaldi Fernández. Universidad de Cantabria. Facultad de Filosofía y Letras. Av. de los Castros, 52. Santander 39005 - adrian.magaldi@unican.es - https://orcid.org/0000-0002-3241-8802

Cómo citar: Magaldi Fernández, Adrián (2019). "La "Operación Roca". El fracaso de un proyecto liberal en la España de los 80»; Historia Contemporánea, 59, 307-342. (https://doi.org/10.1387/hc.19201).

Recibido: 8 febrero, 2018; aceptado: 17 abril, 2018.

ISSN 1130-2402 - elSSN 2340-0277 / (C) 2019 UPV/EHU 


\section{Introducción}

Las elecciones del 28 de octubre de 1982 supusieron un completo fracaso para el hasta entonces partido del Gobierno, Unión de Centro Democrático (UCD), que se vio reducido a una presencia testimonial con solo 11 diputados, por lo que la formación no tardó en disolverse. La UCD, una vez aprobada la Constitución, había revelado el que venía siendo su principal problema desde su nacimiento: la falta de una base ideológica común ${ }^{1}$. Si democristianos, liberales y socialdemócratas habían estado de acuerdo en la moderación que debía caracterizar el proceso de cambio, una vez que este había culminado con éxito, sus diferencias hacían imposible la convivencia en un mismo partido ${ }^{2}$. Estas desavenencias no hicieron sino acentuarse con el abandono de la presidencia del Gobierno por parte de Adolfo Suárez en enero de 1981, desapareciendo «el clavillo del abanico que mantuvo frágilmente juntas las varillas - familias de $U C D »^{3}$. En estas circunstancias, su previsible hundimiento electoral no hizo sino confirmarse cuando los ciudadanos fueron llamados a las urnas en 1982. Para entonces hacía tiempo que gran parte de sus miembros ya habían encontrado lugar en otros partidos. Los socialdemócratas habían creado el Partido de Acción Democrática que, liderado por Francisco Fernández Ordoñez, concurrió a las elecciones coaligado al PSOE para, poco después, aprobar su disolución. Por su parte, los democristianos habían creado el Partido Demócrata Popular (PDP) que, con Óscar Alzaga al frente, se presentó en coalición con Alianza Popular (AP). También el llamado sector suarista había creado su propio partido, el Centro Democrático y Social $(\mathrm{CDS})^{4}$. Entre los diversos sectores que fueron abandonando UCD y planteando su alternativa ante el previsible fracaso ucedista, el gran ausente fue el sector liberal. Mientras los socialdemócratas acentuaron su carácter izquierdista y los democristianos sus principios más conservadores, el sector liberal se encontró con la dificultad de erigirse como

1 Junto al problema ideológico arrastrado desde sus orígenes, la UCD también tuvo que hacer frente a otra serie de problemas planteados progresivamente como las pugnas por el liderazgo, el debilitamiento de la jefatura de Adolfo Suárez o los diferentes modelos de partido que se discutían en el seno de la formación centrista. Sobre el hundimiento de UCD, véase: Gunther, 1986, pp. 433-492.

2 Huneeus, 1985, pp. 306-332.

3 Calvo-Sotelo, 1990, p. 32.

4 Alonso-Castrillo, 1996, pp. 500-519. 
nueva alternativa centrista desde el mismo centro en que ya se encontraba. Sus problemas se vieron acrecentados por la pérdida de su principal líder, Joaquín Garrigues Walker, quien falleció en 1980 enfermo de leucemia. Los liberales fueron así los grandes perdedores, los auténticos huérfanos tras la muerte de UCD. Antonio Garrigues Walker, hermano de Joaquín, ya había intentado crear, en el verano de 1982, un Partido Demócrata Liberal (PDL) en torno a dicha ideología, pero encontró serias dificultades. El gran impulso llegó, ya constatado el fracaso de UCD, desde aquellos sectores que habían ocupado cargos de segundo nivel en la administración y desde las viejas élites provinciales ucedistas, situadas en un centrismo más sociológico que ideológico autodefinido como reformista en contraposición a socialistas y conservadores.

Pero la alternativa liberal padecía la falta de un auténtico líder, pues Antonio Garrigues, a pesar de su reconocimiento profesional, no había logrado capitalizar el prestigio que había dejado su hermano. Así fue surgiendo la idea del posible liderazgo de Miquel Roca. Además de uno de los padres de la Constitución, Roca se trataba en esos momentos de un prestigioso parlamentario al frente del grupo de Convergència i Unió (CiU) en el Congreso, cuya dirección asumió desde que Jordi Pujol abandonase la política nacional en 1980 para ponerse al frente de la Generalitat. El propio Roca hacía tiempo que venía contemplando la posibilidad de impulsar un partido liberal de ámbito nacional ante la previsible desaparición de UCD y la ausencia en España de una formación liberal, reformista y europeísta, espacio que consideraba estaba representado en Cataluña por Convergència. Ya antes de las elecciones de 1982 Roca publicó una obra, Per qué no? Una proposta catalana per a la modernització de l'estat, en la que se reflejaban dichos intereses y gran parte de las ideas sobre las que se vertebraría el futuro proyecto reformista ${ }^{5}$. Fue la aparición de diversos partidos que aspiraban a ocupar el espacio centrista en dichas elecciones lo que le llevó a retrasar su iniciativa. Según Jordi Pujol, una vez celebradas las elecciones del 82 y constatado el hundimiento de UCD y la aplastante mayoría absoluta de Felipe González, Roca le indicó la necesidad de poner en marcha el proyecto reformista porque, de lo contrario, «lo tenemos muy mal. AP no es un partido que pueda contrarrestar al PSOE y durante mucho tiempo la política española estará desequilibrada ${ }^{6}$.

5 Roca, 1982.

6 Pujol, 2009, p. 150. 
En esta situación, los sectores huérfanos de UCD no tardaron en fijarse en este potencial líder. Luis Marín, al frente del grupo centrista del parlamento andaluz, recuerda que, en enero de 1983, recibió la llamada de un excompañero de UCD, Joaquín García Romanillos, invitándole a una reunión en Madrid para, junto a otros viejos compañeros centristas, promover un nuevo partido. Marín viajó a Madrid y fue allí donde Florentino Pérez le presentó el proyecto ante la necesidad de articular una nueva opción de centro «si no queríamos que el PSOE se eternizara en el poder» ${ }^{7}$. Para Marín, las principales dudas giraban en torno al liderazgo de la operación, pues

«era imprescindible visualizar la oferta que buscábamos en un político que la reflejara nítidamente. Y ahí llego para mí el dato definitivo:

- Miguel Roca - me dijo Florentino.

- ¿Roca? - exclamé gratamente sorprendido-. Es el mejor parlamentario y la mejor imagen de liberalismo moderado que podíamos soñar, pero no sé si aceptaría un reto de ámbito nacional - aduje.

Y Florentino con absoluta seguridad me dijo: ya he hablado con él, y está dispuesto a dar el paso si comprueba que hay un mínimo de posibilidades.» ${ }^{8}$

Se ponía en marcha la Operación Reformista, también conocida como Operación Roca, la cual se basaría en el liderazgo de Miquel Roca y el impulso de los sectores huérfanos de la desaparecida UCD. También sumó a la prestigiosa figura de Antonio Garrigues Walker, el primero que había planteado la necesidad de una opción liberal y pieza fundamental que, gracias a su adscripción a la Internacional Liberal, aportó el reconocimiento internacional a la formación.

A lo largo de las siguientes páginas se analizarán desde los primeros intentos puestos en marcha por Antonio Garrigues por crear un partido liberal, hasta la definitiva creación del Partido Reformista Democrático (PRD) y su intento de llevar a la presidencia a Miquel Roca en las elecciones de 1986, intentando comprender las razones que provocaron el fracaso de esta alternativa política.

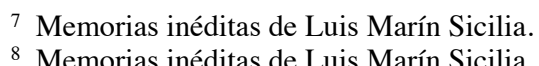




\section{Antonio Garrigues Walker y el Partido Demócrata Liberal}

Antonio Garrigues Walker fue el primero en apostar por un proyecto político liberal apartado de ese «centrismo indefinido» que representaba una UCD con pretensiones de catch-all party. Desde joven había mostrado una clara vocación política, pero había sido su hermano Joaquín el que saltara a la primera línea política durante la Transición. Joaquín Garrigues Walker había impulsado, tras la muerte de Franco, la Federación de Partidos Demócratas y Liberales que, junto al Partido Demócrata Popular de Ignacio Camuñas, constituyeron la familia liberal de UCD. Joaquín Garrigues, que pronto se convirtió en líder indiscutible del sector liberal ucedista, ocupó la cartera de Obras Públicas (1977-1979) y, posteriormente, el Ministerio Adjunto a la Presidencia (1979-1980), un cargo más simbólico que real dada la imposibilidad de ejercer un cargo efectivo por su enfermedad ${ }^{9}$. Mientras, Antonio Garrigues Walker se dedicó a la presidencia del prestigioso despacho de abogados Garrigues y, desde 1976, a la dirección de la Asociación para el Progreso de la Dirección (APD), una comunidad de directivos dedicada a la discusión y el debate político-económico ${ }^{10}$. Las tertulias y reuniones mantenidas en torno a la APD derivaron, en diciembre de 1977, en el nacimiento del Club Liberal, centrado en el debate sobre la necesidad de impulsar en España una auténtica alternativa liberal ${ }^{11}$. Así comenzaron a fundarse por toda España unos Clubs Liberales inspirados en los clubs Perspectives et Realités, nacidos en Francia durante los años 60 bajo el impulso de Michel Poniatowski, mano derecha de Giscard d'Estaing, con el propósito de unir a los simpatizantes de los Republicanos Independientes y conseguir la llegada de Giscard al Elíseo. El propio Garrigues viajó a París para reunirse con los responsables franceses de los clubs, que le proporcionaron información sobre la forma en que habían desarrollado aquella operación en el país galo. De esta forma fue articulándose en España un grupo que planteaba su posible conversión en un partido político liberal, idea que cobró mayor fuerza tras la muerte de Joaquín Garrigues Walker y la imagen generalizada de que era su hermano Antonio el llamado a coger el relevo.

Ante la crisis de UCD, y el creciente prestigio de Antonio Garrigues y su posible opción liberal, en agosto de 1981 el entonces presidente del

\footnotetext{
$9 \mathrm{Pi}, 1979$.

10 Caldés y Garrigues Walker, 1983, p. 48.

11 García-León y Martínez-Echevarría, 2014, pp. 109-110.
} 
Gobierno, Leopoldo Calvo-Sotelo, intentó atraerlo hacia UCD y le ofreció la cartera de Justicia, que había quedado vacante tras la marcha de Francisco Fernández Ordóñez. Garrigues rechazó el cargo al no estar dispuesto a «manchar» su futuro con un partido en decadencia que dificultara sus posibilidades futuras. Además, Garrigues siempre había mostrado sus reparos a una posible integración en UCD, que consideraba «un partido católico en donde no es posible el liberalismo» ${ }^{12}$. Pero los sectores liberales de UCD contemplaban las posibilidades que les ofrecía Garrigues y la necesidad de encontrar una solución a su futuro político. Luis Miguel Enciso, miembro del Comité Ejecutivo de UCD, defendió que se aceptasen las tendencias internas en el partido tal y como habían existido en sus orígenes, lo que desde su visión posibilitaría la incorporación de Garrigues y la articulación de un auténtico grupo liberal, aunque fuera como parte de UCD. Otro liberal ucedista, Joaquín Muñoz Peirats, consideraba igualmente que el partido debía conformarse en torno a dos ideologías, la liberal y la democristiana, a lo que dedicó amplios esfuerzos que acabaron causándole su expulsión del partido ${ }^{13}$.

Con UCD entretenida en discutir su proyecto de futuro, los diversos Clubs Liberales creados por toda España constituyeron en febrero de 1982 la Federación de Clubs Liberales. Garrigues fue elegido Presidente, y los ucedistas Eduardo Merigó y Eduard Punset fueron nombrados vicepresidente y Secretario General, respectivamente. De los 21 cargos directivos que se eligieron, 12 recayeron en miembros del partido centrista. En el discurso de clausura, Garrigues indicó su propósito de impulsar un auténtico partido liberal, tanto en lo económico como en lo político, con lo que trataba de marcar distancias con el neoliberalismo de Margaret Thatcher y Ronald Reagan, a quienes criticó abiertamente ${ }^{14}$. Según Garrigues

«Nosotros no [estábamos] con el neoliberalismo de la época, creíamos en un liberalismo más abierto, más progresista, en donde no se sacralizaran demasiadas cosas y que el liberalismo no se limitara al aspecto económico. No queríamos que ser liberal fuera simplemente ser defensor de la economía de libre mercado. La idea básica es que además de defender la economía de mercado, y no siempre, había que defender todas las demás libertades y, en concreto, poner en marcha el

\footnotetext{
12 El País, 23-X-1980.

13 El País, 6-VII-1982.

14 Diariol6, 27-II-1982.
} 
proceso de liberalización del individuo frente al poder del Estado, el poder de la Iglesia, el poder de la cultura, en definitiva, la liberación del ser humano de todos los poderes.» ${ }^{15}$

Se ponía en marcha un proyecto liberal con la declarada vocación de «ocupar el espacio electoral del centro» y convertirse en «el partido-bisagra» de la política española, «porque la bisagra te da una fuerza política sorprendente, no porque tengas votos, sino porque tienes una capacidad de maniobra política muy seria» ${ }^{16}$. La iniciativa no tardó en contar con apoyos internacionales, especialmente del Ministro de Asuntos Exteriores alemán, Hans-Dietrich Genscher, quien cumplía en la política germana esa función de partido-bisagra desde un espacio liberal. Garrigues viajó a Alemania, donde se reunió con Genscher y Verheugen, Secretario General del Partido Liberal Democrático de Alemania, para tratar las posibilidades que un partido liberal tendría en España, especulándose con su lanzamiento en el mes de septiembre ${ }^{17}$.

La crisis de UCD precipitó los acontecimientos, y el adelanto de las elecciones que debían celebrarse en marzo de 1983 ya se daba por seguro en los círculos políticos. Esto llevó a que el 13 de julio de 1982 Garrigues constituyese el Partido Demócrata Liberal (PDL), cuyas bases sociales fueron mayoritariamente aportadas por los Clubs Liberales, aunque se decidió no disolver estos y que pervivieran como una organización independiente centrada en el debate intelectual sobre las líneas que podría seguir el partido en su actuación política. El PDL diseñó un programa basado, como ya había manifestado Garrigues, en un liberalismo no sólo económico sino también político, defendiendo las libertades del ciudadano desde un programa que no tardó en calificarse de liberalismo de izquierdas o radicalismo, comparable al de Marco Pannella en Italia ${ }^{18}$. El propio Garrigues se definió como un liberal progresista, afirmando que «el concepto de liberalismo conservador no me es grato y siempre he pensado que entre ambos términos - liberal y conservador - existe una evidente contradicción: el liberalismo debe ser forzosamente progresista, y aquellos que defienden el liberalismo conservador suelen ser, simplemente, conservadores que utilizan el adjetivo liberal para tranquilizar sus con-

\footnotetext{
15 Entrevista a Antonio Garrigues Walker, 27-IV-2017.

16 Entrevista a Antonio Garrigues Walker, 27-IV-2017.

17 ABC, 27-I-1982.

18 Diariol6, 15-I-1983.
} 
ciencias y vender mejor su producto» ${ }^{19}$. Su programa ideológico se basaba en una reducción de la intervención del Estado, no sólo en materia económica, sino también sobre la vida del individuo. Garrigues manifestaba que el Estado sólo debía intervenir

«en aquellos campos en que, por la naturaleza misma del ámbito, o por una dejación clara de la sociedad, no alcanza la iniciativa privada. El Estado debe existir. Correcto. Pero como encargado de regular la convivencia social, no de reprimirla en su espontaneidad. El peligro nace cuando la sociedad deja de controlar al Estado y éste se convierte en regulador de los comportamientos sociales, y en vez de obedecer a la sociedad, decide ordenar y mandar. Y este riesgo no sólo aparece en el mundo de la economía, sino también en el de la cultura, el pensamiento, las relaciones familiares... ${ }^{20}$

A partir de estas ideas, Garrigues desarrollaba un programa de liberalismo económico, con una intervención del Estado reducida a sectores clave (sanidad, educación...); así como una serie de importantes libertades ciudadanas, que le llevaban a apoyar la legalización del aborto, de las drogas blandas, declarando haber «fumado porros de vez en cuando» ${ }^{21}, \mathrm{o}$ de la eutanasia, que consideraba parte del «reconocimiento del derecho a la propia vida, y, por ello, a quitarse la vida ${ }^{22}$.

En este contexto en que Garrigues iba defendiendo su futura alternativa liberal, Calvo-Sotelo adelantó oficialmente las elecciones al 28 de octubre de 1982. El PDL se encontró con el problema de decidir cómo competir, pues todavía no había alcanzado la suficiente articulación y expansión nacional. Algunos plantearon sumarse a la coalición formada por AP-PDP, como Bernardo Rabas, Alejandro Arráez y Luis Guzmán, propuesta que no salió adelante por el rechazo de Garrigues. No obstante, algunos miembros del Club Liberal se sumaron a la candidatura de Fraga, como Pedro Schwartz, aunque este no militaba en el PDL y estaba alineado en unas posiciones neoliberales rechazadas por Garrigues ${ }^{23}$. Desde el PDL se impuso la idea de formar coalición con UCD, y el 9 de septiembre Garrigues alcanzó un acuerdo con Landelino Lavilla, quien había

19 Caldés y Garrigues Walker, 1983, p. 26.

${ }^{20}$ Ibídem, p. 71.

21 Ibídem, pp. 212-213.

22 Ibídem, p. 204.

23 VV.AA., 1984, p 21. 
sido elegido candidato por la formación centrista. UCD y PDL concurrirían juntos a las elecciones, pero manteniendo su independencia y respetándose las siglas de ambos partidos. La principal dificultad encontrada fue respecto al porcentaje de liberales que optarían a escaño, tema que se aplazó para posteriores conversaciones ${ }^{24}$. El acuerdo sobre las listas se planteaba difícil de alcanzar, con reparos por parte de UCD a ceder puestos a los liberales ante el más que previsible hundimiento electoral. Esto sería causa de importantes tensiones, que llegaron a sus máximos niveles en la elaboración de las listas por Madrid, donde Garrigues exigía figurar en el tercer puesto, petición rechazada por una UCD que reservaba dicha posición para el entonces ministro del Interior, Juan José Rosón. El 19 de septiembre el PDL decidió romper la coalición, advirtiendo Garrigues que «UCD sin los liberales es como Alianza Popular» ${ }^{25}$. Roto el acuerdo, el PDL optó por no concurrir a las elecciones para reducir la oferta centrista ante el electorado. Garrigues consideraba que lo mejor era esperar al escenario que surgiera tras las elecciones, pues «lo importante era, y es, dotar al liberalismo de una identidad propia y fuerte» ${ }^{26}$. Las únicas excepciones a tal decisión fueron el País Vasco, donde el PDL se sumó a la candidatura conjunta formada por AP, PDP, UCD y PDL debido a la singularidad política vasca; y las candidaturas de Convergencia Canaria y Partido Asturiano Demócrata Liberal, con bajos resultados y sin ningún diputado. Pero su «fracaso» pasó inadvertido ante el hundimiento de UCD y los escasos 2 diputados conseguidos por la fórmula centrista de Adolfo Suárez. La situación surgida de las urnas daba fuerzas a los miembros del PDL para tratar de convertir a su partido en la nueva alternativa centrista española.

El 15 de enero de 1983 el PDL celebró su I Congreso oficializando su proyecto político. Garrigues fue elegido Presidente mientras Justino de Azcárate y Luis Miguel Enciso fueron designados vicepresidentes. Por su parte, Pedro López Giménez, que había sido Secretario de Organización de UCD, asumió la Secretaría General. Garrigues declaró que el objetivo del PDL era convertirse en un partido de masas y ser el nuevo representante del centro ante un Parlamento que consideraba polarizado, «puesto que el exiguo centrismo allá presente no consigue ni siquiera mitigar apenas la tensión existente entre las dos grandes fuerzas que dominan la Cá-

\footnotetext{
${ }^{24}$ El País, 10-IX-1982.

25 El País, 20-IX-1982.

26 ABC, 30-IX-1982.
} 
mara», marcándose como objetivo «que el espacio de centro vuelva a ser importante en la política del Estado» ${ }^{27}$. El PDL aspiraba a convertirse en el partido-bisagra clave de la política nacional ante «la necesidad de una fuerza intermedia de carácter liberal progresista que cumpla dos funciones principales: por un lado, recoger todo el voto marginal que han cosechado socialistas y aliancistas por falta de otras ofertas [...], de otro lado, moderar, y hasta arbitrar, la tensión dialéctica entre la derecha y la izquierda», aunque Garrigues afirmaba sentirse mucho más cerca del PSOE que de Fraga $^{28}$.

Ante la articulación de una posible alternativa en torno al PDL, que además había sido admitido en la Internacional Liberal, Fraga trató de impulsar el brazo liberal que le faltaba a su Coalición Popular, nombre con el que empezó a denominarse a la unión AP-PDP. La voluntad de Fraga por alcanzar su deseada «mayoría natural» se basó, más que en modificar y moderar su programa aliancista, en tratar de vincular a su persona todo el espectro ideológico no socialista, faltándole esa «guinda liberal» con la cual poder restar apoyos a Garrigues ${ }^{29}$. Así nació la Unión Liberal (UL), creada bajo el patrocinio encubierto de AP por Pedro Schwartz. Este trató de ganarse el apoyo de los Clubs Liberales que, a pesar de su vinculación con el PDL, seguían manteniendo cierta independencia. Para ello, Schwartz inscribió en los clubs a sus partidarios y llegó a pagar sus cuotas, con lo que perseguía ganar una votación en la que los clubs declarasen su apoyo a la UL. Las maniobras de Schwartz fracasaron, pese a lo cual los clubs aprobaron servir tanto al PDL como a la UL ${ }^{30}$. El impacto real de la UL fue reducido, pero logró atraer a figuras tan destacadas como Fernando Chueca Goitia, que había participado en la redacción del manifiesto fundacional del PDL, y que fue nombrado presidente de la nueva formación. En febrero de 1983 se oficializó el nacimiento de Unión Liberal, que nunca llegó a ser un auténtico partido, con un liderazgo débil, una escasa estructura y unos fondos reducidos, ya que Fraga no parecía estar dispuesto a que «la criatura» creciera demasiado y acabase adquiriendo cierta autonomía ${ }^{31}$.

\footnotetext{
27 ABC, 17-XII-1982.

${ }^{28}$ Caldés y Garrigues Walker, 1983, p. 170.

${ }_{29}$ Powell, 2013, p. 392.

30 Penella, 2005, pp. 673-676.

31 Ibídem, p. 679.
} 
Mientras, el PDL estaba centrado en las elecciones autonómicas y municipales convocadas para el 8 de mayo de 1983. Sectores del PDL y el CDS apostaron por una candidatura conjunta que en la capital del Estado encabezase el propio Garrigues, pero la coalición no fue posible. Suárez trató de imponer sus nombres, proponiendo para la capital a Rosa Posadas en lugar de al líder liberal; y Garrigues mostró abiertos reparos hacia el CDS, pues consideraba que «Suárez defiende una no muy concreta actitud populista, que tiene mucho de intuitiva, por una parte, y bastante de socialdemócrata en los planteamientos prácticos, por otra ${ }^{32}$. Concurriendo finalmente en solitario, el principal problema que encontró el PDL fue su escasa cobertura en los medios públicos, por lo que Garrigues encabezó una protesta junto a un centenar de militantes ante las instalaciones de Televisión Española por la discriminación informativa que, en su opinión, sufrían los liberales. Frente a este problema, el partido impulsó una televisión pirata, Antena Libertad, con la cual promocionar a la formación liberal ${ }^{33}$. Cuando se celebraron las elecciones municipales, Garrigues cosechó un rotundo fracaso en Madrid, obteniendo tan solo 44.159 votos, lo que suponía un $2,65 \%$ y ningún concejal. Además, Garrigues había visto cómo su candidatura era superada por la del CDS, aunque este tampoco obtuvo ningún concejal. En el resto de España los resultados fueron similares, obteniendo 861 concejales, lo que suponía un resultado testimonial. Además, sólo obtuvo representación en tres capitales: Ceuta ( 2 concejales), Santiago de Compostela (3 concejales) y Segovia (1 concejal). A escala autonómica el resultado fue similar y apenas se superó el $1 \%$ de los votos en aquellas comunidades que habían presentado candidatura. Únicamente se obtuvieron dos diputados, uno en Castilla y León y el otro en Baleares, derivados más del prestigio de los candidatos que de las siglas que representaban ${ }^{34}$. Igualmente obtuvo en Canarias un diputado la candidatura de Convergencia Canaria, que contaba con el apoyo del PDL.

32 Caldés y Garrigues Walker, 1983, p.163.

33 Entrevista a Antonio Garrigues Walker, 27-IV-2017.

${ }^{34}$ Los elegidos fueron Francisco Montoya Ramos como diputado en las Cortes de Castilla y León por la provincia de Burgos, donde había sido el primer presidente democrático de la diputación. Por su parte, el miembro elegido en el Parlamento balear era Alonso Marí Calbet, destacado empresario y vicepresidente de la Asamblea de Partidos Políticos de Ibiza y Formentera. 


\section{Cuadro 1}

Resultados del PDL en las elecciones autonómicas de $1983^{35}$

\begin{tabular}{lccc}
\hline \multicolumn{1}{c}{ Comunidad } & Votos & Porcentaje & Escaños \\
\hline Aragón $^{\mathrm{a}}$ & 883 & $0,15 \%$ & 0 \\
Asturias $^{\text {Baleares }}{ }^{\mathrm{b}}$ & - & - & - \\
Canarias $_{\text {Cantabria }}$ & 3.896 & $1,27 \%$ & 1 \\
Castilla-La Mancha $^{\mathrm{c}}$ & 24.479 & $4,42 \%$ & 1 \\
Castilla y León $^{\mathrm{d}}$ & 4.474 & $1,61 \%$ & 0 \\
Comunidad Valenciana $^{\text {Extremadura }}$ & 15.890 & $1,79 \%$ & 0 \\
La Rioja & 49.268 & $3,63 \%$ & 1 \\
Madrid & 29.788 & $1,57 \%$ & 0 \\
Murcia & - & - & - \\
Navarra & - & - & - \\
\hline
\end{tabular}

a) Solo presentó candidatura en la provincia de Huesca.

b) Solo presentó candidatura en Ibiza y Formentera.

c) Solo presentó candidaturas en las provincias de Cuenca, Guadalajara y Toledo.

d) Solo presentó candidaturas en las provincias de Burgos, León, Segovia y Zamora.

Fuente: https://www.datoselecciones.com/ [Consulta realizada en abril de 2018].

Las elecciones municipales y autonómicas de 1983 venían a confirmar el escenario bipartidista que había comenzado a configurarse tras las elecciones generales de octubre del 82, con un PSOE como partido dominante con una progresiva moderación en sus postulados, y un «sub-triunfo de la derecha» aliancista al incorporar a grupos democristianos y «liberales» que habían contribuido a templar la imagen de Fraga ${ }^{36}$. Parecía que ese potencial electorado centrista había optado por una polarización de su voto ante la moderación de la derecha y la izquierda. Esto, unido a las dificultades encontradas por el PDL para difundir su mensaje en los me-

35 En Asturias, Extremadura, La Rioja y Navarra el PDL no presentó candidatura; mientras que en otras regiones sólo se presentó en determinadas provincias. Asimismo, en Canarias se incluyen los datos referidos a la candidatura de Convergencia Canaria, respaldada por la formación de Garrigues.

${ }^{36}$ Montero, 1986, pp. 345-432. 
dios públicos, así como la falta de una estructura suficiente para presentar candidatos en todas las circunscripciones, debilitaron su imagen de alternativa de poder y redujeron sus potenciales apoyos electorales. Estas dificultades llevaron a Garrigues a replantearse la estrategia del partido y meditar si era conveniente realizar un acercamiento a Fraga similar al de los democristianos de Óscar Alzaga ${ }^{37}$. Fue entonces cuando Garrigues encontró el apoyo de CiU para sumarse a ese proyecto reformista que estaban tratando de poner en marcha junto a los viejos ucedistas huérfanos para articular una potente alternativa centrista al confiar en que el perfil moderado del electorado acabaría posibilitando un nuevo proyecto de centro en España. Garrigues se acercaba a la Operación Roca y, en noviembre de 1983, el PDL aprobó en su II Congreso apoyar dicha estrategia, así como su futura disolución cuando esa operación cristalizara en un nuevo partido político.

\section{El nacimiento del Partido Reformista Democrático}

Fue el fracaso de su estrategia en solitario lo que llevó a los liberales de Garrigues a acercarse a la Operación Roca, aunque esta hacía meses que había nacido impulsada por los sectores huérfanos del centrismo ucedista. Los primeros en reunirse fueron altos cargos de la Administración, procedentes de puestos de segundo nivel de los diferentes ministerios. Como señala Fernando Jáuregui, las desavenencias internas que produjeron el hundimiento de UCD se habían producido básicamente entre los barones, es decir, entre los miembros del Gobierno o del grupo parlamentario. Pero este no era el caso en los niveles intermedios de la Administración, entre los que existía un grado de entendimiento notable. El 18 de diciembre de 1982 dichos contactos se oficializaron dando lugar a una primera Comisión en la que figuraron personas como Florentino Pérez (que había sido presidente del IRYDA con José Luis Álvarez), Joaquín García Romanillos (director general de Justicia con Pío Cabanillas), Luis Enríquez de Salamanca (director general del INUR con Jesús Sancho Rof), José Sánchez Bernal (director general de Trabajo con Santiago Rodríguez de Miranda), Miguel Ángel Arroyo (subsecretario de Educación con Juan Antonio Ortega Díaz-Ambrona), Juan Jesús Lasca (secretario general téc-

37 García-León y Martínez-Echevarría, 2014, p.137. 
nico de Hacienda con Jaime García Añoveros), Antonio Botella (subsecretario de Agricultura con José Luis Álvarez) o Matías Vallés (director general de cine con Íñigo Cavero) ${ }^{38}$. En un primer momento, el grupo estuvo reducido a figuras del segundo nivel de la Administración ligadas estrictamente a los centros políticos madrileños, pero no tardaron en expandirse por el resto del país y encontrar el apoyo en unos líderes provinciales y locales que se habían quedado sin partido. La comisión sectorial existente hasta entonces se transformó, en febrero de 1983, en una comisión territorial, incorporando a un proyecto que ya comenzaba a denominarse reformista a figuras como Luis Marín, al frente de los centristas andaluces en el parlamento regional; Gregorio Toledo, de Convergencia Canaria; Ramón Ponce, al frente del Grupo Independiente de Almería; el malagueño José Carlos Aguilar, antiguo secretario general de las Juventudes Centristas; Jerónimo Albertí, Presidente de Unión Mallorquina; así como otros viejos dirigentes regionales de $\mathrm{UCD}^{39}$. Paralelamente se iniciaron contactos con Miquel Roca a través de Luis Enríquez de Salamanca, con quien tenía cierta relación personal. El encuentro se llevó a cabo en el restaurante Zalacaín, y a él acudieron el propio Enríquez, Florentino Pérez y Miquel Roca. Lo que ofrecieron al dirigente catalán era ponerse al frente de una operación de centro reformista y liberal y convertirse en el nuevo Cambó de la política española. Esta idea conectaba perfectamente con la que ya existía en la mente de Roca de poner en marcha un proyecto que enlazara con el catalanismo histórico representado por Valentí Almirall, Francesc Cambó o Enric Prat de la Riba, y que cumpliera dos objetivos: el reconocimiento lingüístico, cultural y político de Cataluña, y la intervención en la política nacional con una doble finalidad, conseguir una estructura estatal acorde con la concepción plural del Estado de los convergentes, y la contribución al progreso general del país ${ }^{40}$.

La presentación pública de la Operación Reformista tuvo lugar el 16 de febrero de ese mismo año en el Club del Sable, donde Roca manifestó sus aspiraciones políticas nacionales. Ese mismo día, personas del entorno de Florentino Pérez acudieron a registrar el Partido Reformista Democrático, aunque por el momento los reformistas continuaron apareciendo como una operación política y no como un auténtico partido ${ }^{41}$. Roca co-

\footnotetext{
38 Jáuregui, 1987, pp. 126-127.

39 Ibídem, p. 128.

40 Pujol, 2009, pp.150-151.

41 Registro General de Partidos Políticos, Ministerio del Interior, c.629.
} 
menzó a viajar por toda la geografía nacional vendiendo la necesidad del proyecto reformista en la política española, pero sin abandonar sus intereses políticos en Cataluña. Esta había sido una condición de Roca, quien aceptaba el liderazgo de la operación a cambio de permanecer en CiU, y con el requisito de que esta se aceptase como la rama catalana del reformismo. Pujol mostró en todo momento su aprobación a dicha operación, pues así Roca se establecería en Madrid, lo que le eliminaba un posible rival destinándolo a un puesto mayor o desgastándolo en el intento, y paralelamente se atraería voto no nacionalista hacia una CiU disfrazada de reformista. Mientras avanzaba la operación, Garrigues todavía se mantenía al margen esperanzado en su resultado en las municipales y autonómicas. No obstante, ya se había celebrado algún encuentro entre Garrigues y el dirigente catalán, interesado este en aprovechar las estructuras del PDL para alcanzar provincias donde no había reformistas, y sumar el reconocimiento de la Internacional Liberal que conllevaba la figura de Garrigues. Además, dado que Roca no pensaba abandonar CiU, era necesario contar con una figura relevante en Madrid, y ante el imposible acuerdo con Adolfo Suárez, quien era la preferencia de Pujol, se optó por Garrigues ${ }^{42}$.

El 13 de octubre de 1983 se constituyó la Comisión Gestora Federal, integrada por 27 personas, con 15 integrantes representando a cada uno de los sectores ministeriales de los impulsores iniciales de la operación, y el resto encargados de áreas territoriales, tratando de dar representación a todas las comunidades autónomas para potenciar la imagen federal que de la operación se quería transmitiri3 ${ }^{43}$ Dicha comisión trató de esquivar las grandes figuras y evitó a los viejos barones y exministros con la única excepción de Juan José Rosón, cercano al proyecto, aunque finalmente no llegara a sumarse como tal. Un mes después comenzaron a celebrarse reuniones por toda España para crear comisiones gestoras provinciales, centradas en atraer a dirigentes de los partidos regionalistas y a los más de 400 alcaldes y 3.000 concejales «independientes» que se correspondían con antiguos dirigentes locales de $\mathrm{UCD}^{44}$. Iba extendiéndose una opción de centro que no tardó en generar temores en otras formaciones. El primero en descalificarlos fue Adolfo Suárez, que definió a los reformistas como una derecha conservadora ante el temor a que la Operación Roca afectara a su naciente CDS. Por su parte, Fraga los culpó de dividir

\footnotetext{
42 Jáuregui, 1987, pp. 148-149.

43 PRD, 1985, p. 25.

44 Memorias inéditas de Luis Marín Sicilia.
} 
fuerzas, mientras el PDP miraba desconfiado que cuajase una alternativa centrista en la que no estaban y los desplazara definitivamente hacia una derecha en la que se encontraban situados con ciertos reparos. Pero los reformistas todavía no habían puesto en marcha el partido como tal, debido a la decisión de Roca de esperar al resultado de CiU en las elecciones catalanas del 29 de abril de 1984, ya que consideraba que un mal resultado podría debilitar las posibilidades de una naciente formación. Esto provocó que los reformistas se volcaran con las elecciones catalanas, recibiendo visitas como la de Luis Marín, al frente de los reformistas andaluces, que visitó las peñas andaluzas, muy numerosas en el «cinturón rojo» de Barcelona, para pedir el voto para Convergència ${ }^{45}$. El triunfo abrumador de $\mathrm{CiU}$, con una aplastante mayoría absoluta, supuso el impulso definitivo que permitió acelerar la constitución formal del Partido Reformista Democrático.

Fueron los días 23, 24 y 25 de noviembre de 1984 cuando, en el Palacio de Congresos de Madrid, se celebró el I Congreso del Partido Reformista Democrático, haciendo efectiva su constitución como partido político. La convocatoria contó con la asistencia de 2.600 compromisarios de toda España, así como destacados liberales extranjeros, atraídos por un Garrigues que, con el nacimiento oficial del PRD, disolvió el PDL e incorporó al reformismo a la Internacional Liberal. Entre los asistentes internacionales se encontraban figuras como Willy de Clerq, Presidente de la Federación Europea de Partidos Liberales y Demócratas, a la que también se incorporó el PRD; Urs Schoettli, Vicepresidente Ejecutivo de la Internacional Liberal; Simone Veil, Presidenta del Grupo Liberal del Parlamento Europeo; Francisco Pinto Balsemão, ex-primer ministro de Portugal; o Virgilio Godoy, Presidente del Partido Liberal Independiente de Nicaragua. También manifestaron su apoyo, a través de carta o telegrama, políticos tan destacados como Hans-Dietrich Genscher, Giovanni Malagodi, Presidente de la Internacional Liberal; Raymond Barre, ex-primer ministro de Francia; o David Steel, Presidente del Partido Liberal Británico ${ }^{46}$. Los diversos partidos liberales del exterior no dudaban así en mostrar su apoyo a una alternativa liberal con importantes posibilidades en España.

El Congreso se inició con la bienvenida de Teresa Mendizábal, Presidenta del PRD de Madrid, quien declaró el propósito reformista de «bo-

\footnotetext{
45 Memorias inéditas de Luis Marín Sicilia.

46 PRD, 1985, pp. 27-29.
} 
rrar definitivamente la España arcaica y mediocre, la España áspera y desvaída [...] que nos impide caminar hacia la modernidad y el progreso» ${ }^{47}$. A continuación, el PRD realizó su declaración ideológica, definiéndose como partido liberal-reformista que pretendía configurarse como la auténtica alternativa a socialistas y conservadores, tal y como declaraba en su eslogan «Por fin, la alternativa». En su declaración ideológica, los reformistas manifestaban:

«El socialismo también se califica de reformista y, en ese sentido, si el análisis de las ideologías políticas se hiciera sólo con el baremo del dinamismo, habría que definir al conservadurismo como estático, y al socialismo y al liberalismo como dinámicos. Sin embargo, el socialismo defiende la transformación de la sociedad hacia fines definidos [...] El liberalismo es progresismo real abierto, que no plantea metas al progreso porque cree que la sociedad irá fijándose, sucesivamente, nuevas cuotas de perfeccionamiento, y que la profundización en la libertad permitirá y facilitará el que la sociedad elija, entre las distintas alternativas, las que abran caminos hacia un futuro mejor. El Partido Reformista Democrático considera que el reformismo, como proceso político, es el método de actuación consustancial con la ideología liberal progresista.» ${ }^{48}$

Su programa definía así su carácter liberal y se marcaba como objetivo la potenciación de la sociedad civil frente al Estado, crítica que partía del contexto político del momento y la influencia que consideraban estaba ejerciendo el PSOE desde el Gobierno en materias como la economía, la educación o la televisión ${ }^{49}$. Esto hacía que los reformistas plantearan una revisión del papel del Estado, demandando una liberación del individuo que, sobre todo, centraron en la esfera económica al defender cuestiones como una limitación del sector público en tanto que agente económico, la disminución del intervencionismo de los poderes públicos en los mercados, y la orientación de todas las políticas generales y sectoriales al fomento de la actividad empresarial y su consiguiente creación de empleo ${ }^{50}$. Con ello se pretendía, paralelamente, reducir el gasto público y disminuir un déficit cuyos efectos, lamentaban, fueran la causa del freno en la in-

\footnotetext{
47 Ibídem, p. 20.

48 PRD, 1984, p. 20.

49 Ibídem, p. 21.

50 Ibídem, p. 22.
} 
versión, el aumento de la inflación o el elevado endeudamiento exterior. Para los reformistas, la empresa pública debía tener «un papel subsidiario, complementario o suplementario, pero nunca concurrencial», aunque matizaban su rechazo «al retorno a un liberalismo salvaje» ${ }^{51}$. Desde esta posición realizaban una crítica abierta a las ideas de Milton Friedman e indicaban que, a pesar de su apuesta por reducir el gasto público, defendían un sistema mixto de sanidad o una cierta planificación por parte del Estado en campos como el energético con el objetivo de impedir posibles monopolios $^{52}$. Pese a estas matizaciones, todas estas medidas orientadas a una reducción del papel del Estado giraban en torno a materias económicas o administrativas, con lo que desaparecía esa apelación a las libertades del individuo que habían caracterizado el discurso radical del PDL. Las medidas sociales se difuminaban en un discurso liberal-demócrata de unos tonos claramente más academicistas.

Junto a estos puntos, el PRD hizo de la cuestión territorial bandera fundamental de su programa. La propia estructura federal del partido confirmada en dicho Congreso así lo reflejaba. Cada delegación regional del PRD tendría una amplia autonomía en la toma de decisiones pero, además, en diversas regiones el partido renunciaba a su presencia en favor de otros grupos regionalistas o nacionalistas que representarían los intereses del PRD en tales comunidades, como fueron los caso de CiU, Convergencia Canaria, Unió Mallorquina o Coalición Galega, un partido impulsado en Galicia por Eulogio Gómez Franqueira sobre los restos del ucedismo en la región y sus redes de influencia caciquil. También hubo contactos con el Partido Nacionalista Vasco (PNV), y el propio Roca se reunió con el vicelehendakari Mario Fernández con la intención de incorporarlos a la Operación Reformista, pero los nacionalistas vascos decidieron mantenerse al margen ${ }^{53}$. Ello llevó al PRD a limitar su actuación en el País Vasco y no articular una federación en Euskadi, pues consideraban que sólo serviría para complicar el escenario político vasco ${ }^{54}$. Ese carácter federal de la estructura del partido era un reflejo claro de sus ideas sobre la organización territorial, abogando por finalizar el proceso de construcción autonómica del Estado como culmen del proceso de transición democrática. Según Roca, «la idea misma de la autonomía, de la descen-

\footnotetext{
51 Papell, 1984, pp. 47-48.

52 PRD, 1984, p.45.

53 El País, 26-I-1983.

54 PRD, 1984, p. 25.
} 
tralización no sólo administrativa sino también política, es indisociable de una sociedad más libre, más moderna y más operativa, socialmente progresista y políticamente estable» ${ }^{55}$, y es que como dijeron los propios reformistas durante su Congreso, «en España democracia y autonomía son dos hechos indisociables ${ }^{56}$. Miembros tan destacados como Luis Marín aseguraron que «el reformismo es la síntesis del centro con el nacionalismo moderno» ${ }^{57}$. Se daba así una unión entre su identidad centrista y la defensa de los intereses regionales, que confrontaban frente a la política de unos socialistas que consideraban no dispuestos a ceder competencias, y unos conservadores, como siempre se referirían a los aliancistas, a quienes acusaban de no creer en el hecho regional. José Quiroga, que había sido Presidente de la Junta de Galicia (1979-1982) y en esos momentos era senador por Orense y miembro de Coalición Galega, aseguraba que

«Desde allí comprendemos la necesidad de la Operación Reformista, quizá mejor que nadie [...] porque, desde nuestra perspectiva contemplamos, como vosotros, el caos al que nos lleva un Gobierno socialista y porque sufrimos, al mismo tiempo, la total incompetencia de un Gobierno de Alianza Popular, cuyo fracaso era previsible al tener que asumir algo en lo que no ha creído nunca ni cree ahora [en referencia al gobierno autonómico gallego encabezado por el aliancista Gerardo Fernández Albor].»58

Los reformistas apostaban por una auténtica descentralización desde una concepción federalista, requiriendo un nuevo modelo de financiación autonómica y una reforma de la administración que evitase duplicidades y delegase de forma clara las responsabilidades en los respectivos gobiernos autonómicos ${ }^{59}$.

Estos constituyeron los puntos básicos del programa. En otros temas de importancia como la política exterior, se limitaron a simples apelaciones a favor de la permanencia en la OTAN o del ingreso español en la CEE, sin realizar planteamientos de mayor profundidad al respecto. Diseñados los puntos básicos del programa, se procedió a elegir a sus dirigentes, siendo designado Antonio Garrigues como Presidente y Florentino

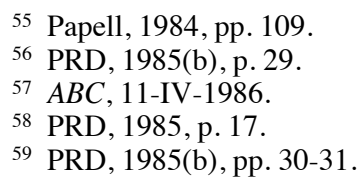


Pérez como Secretario General. Igualmente se nombró la Comisión Ejecutiva del partido, entre cuyos vocales destacaban figuras como Joaquín Satrústegui o Justino de Azcárate ${ }^{60}$. El gran ausente entre los cargos directivos de la formación fue Miquel Roca, quien quedaba como un indefinido líder del reformismo y futuro candidato a la presidencia del Gobierno. Se daba así una situación paradójica difícil de comprender, con Roca como futuro candidato del PRD, pero sin ocupar ningún cargo orgánico en su ejecutiva y sin ser militante del mismo, teniendo en cambio responsabilidades en Convergència, un partido federado a la Operación Reformista pero independiente del PRD. A pesar de esto, el propio Florentino Pérez no dudó en reiterar la importancia de Roca para el futuro de la operación, pues «en último término estamos aquí por un hombre [...]. Es obvio que la esperanza en poder desarrollar nuestras ideas al servicio de la sociedad española ha sido posible por contar entre nosotros con Miguel Roca, capaz tanto de servir de punto de referencia y de identificación para el conjunto social, como de orientar todos nuestros esfuerzos» ${ }^{61}$.

El programa fue bien recibido por importantes sectores de la alta sociedad madrileña y, especialmente, por la banca y la patronal, pues José María Cuevas, Presidente de la CEOE, desconfiaba de las posibilidades de Fraga para derrotar a Felipe González. La Operación Roca también recibió el apoyo de Grupo16, cuyo director, Pedro J. Ramírez, puso los medios del grupo al servicio de la nueva opción electoral que acababa de nacer. Fueron muchas las esperanzas depositadas en un PRD que no aspiraba a ser un mero partido liberal que cumpliera las funciones de bisagra a las que había apelado Garrigues, sino que confiaba en convertirse en una auténtica alternativa de poder ante su confianza en el desgaste socialista y la incapacidad de AP de erigirse como alternativa de poder. Como señalaba el periodista Antonio Papell, «el reformismo, tal y como lo concibe Miquel Roca, no es, pues, una «tercera vía», ni una maniobra «bisagrista», sino una opción completa, bien caracterizada, que trata de competir, en plano de igualdad, con las otras opciones; que tiene, por lo tanto, vocación de poder y de mayoría» ${ }^{62}$.

La Operación Roca, a finales de 1984, quedaba ya configurada como una nueva formación política, el Partido Reformista Democrático, que aspiraba a convertirse en la gran sorpresa de las elecciones de 1986.

\footnotetext{
60 PRD, 1985, p. 41.

${ }^{61}$ PRD, 1985(b), pp. 25-26.

62 Papell, 1984, pp. 153-154.
} 


\section{El impacto de la alternativa reformista}

Celebrado su I Congreso, el PRD continuó su expansión nacional e integró nuevos partidos regionales, como el Partido Riojano Progresista. Igualmente entablaron contacto con el Partido Regionalista de Cantabria y el Partido Andalucista, pero no se alcanzó un acuerdo con ninguno de ellos. Iba produciéndose el desarrollo de una alternativa reformista, con un crecimiento que se nutrió principalmente de antiguos ucedistas, pues hasta un 90\% de los integrantes del PRD habían militado en algún momento en las filas de $\mathrm{UCD}^{63}$. Esto llevó incluso a plantear la posible conversión del pequeño grupo parlamentario centrista que todavía permanecía en el Congreso en el grupo parlamentario reformista, de un modo similar a como lo había hecho en el parlamento andaluz Luis Marín ${ }^{64}$. El principal interés en dicha conversión residía en el beneficio que obtendría el PRD al poder contar con mayores espacios televisivos en la próxima campaña tal y como contemplaba el proyecto de ley electoral que entonces se estaba redactando ${ }^{65}$. Sin embargo, la conversión del grupo centrista no llegó a producirse.

Su expansión no tardó en generar el temor de otras fuerzas políticas que aspiraban a ocupar el mismo espacio que deseaban los reformistas. El mayor choque se produjo con el Centro Democrático y Social. Este partido, al igual que UCD, carecía de una ideología clara y de un proyecto político definido, y su mayor capital político era el propio Adolfo Suárez. Este imprimió al partido un carácter de centro progresista con ciertos aires populistas en lo que algunos han considerado un programa electoral «moderadamente radical» ${ }^{66}$. Pero su programa no partía de unas reflexiones en torno a un liberalismo de izquierdas como había sido el caso de Garrigues, sino que se trataba de una mezcla del viejo discurso social de la revolución pendiente, con una serie de proclamas anti-establishment en muchos casos fruto de sus propios choques con la banca o el ejército ${ }^{67}$. En otras cuestiones, el CDS y Adolfo Suárez mostraron su visión moral conservadora, como se evidenció durante el de-

\footnotetext{
${ }^{63}$ Díez, 2017, p. 237.

${ }^{64}$ La Voz de Córdoba, 6-III-1983.

65 El País, 23-II-1985.

66 Díez, 2017, p. 275.

${ }^{67}$ González, 2000, pp. 475-476.
} 
bate sobre la despenalización del aborto ${ }^{68}$. En realidad, como señalaba Cambio 16:

«El [electorado] suarista es totalmente distinto del de Roca. [...] [La de Suárez] es gente de origen humilde y que no ha prosperado demasiado en la vida. Al margen de los profesores universitarios y profesionales liberales que ha conservado el duque de tiempos de UCD, [...] [se trata de] buena gente, de la que te echa una mano, que en muchos casos conserva en el rostro las huellas de un pasado rural. Son seguramente católicos, de origen ideológico inequívocamente derechista, pero que, como en el caso de Suárez, se han echado al monte de «lo social». Serían neofalangistas si no tuvieran a gala representar o ser representados por el hombre que hizo posible que la libertad volviera y floreciera en España.» ${ }^{69}$

Pese a estas diferencias, tanto CDS como PRD aspiraban a atraer a los antiguos votantes centristas, partiendo la formación suarista con la ventaja de contar con la figura del que había sido Presidente del anterior proyecto centrista de la UCD. El CDS había logrado ser percibido como el auténtico partido del centro (situándolo en un 5'5 en una escala del 1 al 10), mientras el PRD era considerado como una formación de centro-derecha (el electorado lo situaba en un 6,2 $)^{70}$.

Inicialmente se habían producido contactos entre Suárez y Pujol relativos a una posible alianza de ambas formaciones, pero el CDS se desmarcó de cualquier posible apoyo a la Operación Roca. Las evidentes dificultades para unir a reformistas y suaristas en un gran partido de centro llevaron a destacados exministros de UCD a la formación de la CEPA (Centro de Estudios Políticos Actuales), una fundación que pretendía ejercer de puente entre ambos. Sus impulsores fueron Juan Antonio García Díez, Rafael Arias-Salgado, Carlos Bustelo, Luis González Seara y, especialmente, Juan José Rosón. Desde CEPA se apostaba por unir a los dos grandes partidos de centro existentes en esos momentos, así como alguna otra pequeña formación, como el Partido de Acción Liberal de Ignacio Camuñas, que acabó integrándose en el CDS. CEPA pretendía alcanzar una alianza de partidos centristas para configurar una auténtica alternativa y con ello impedir que los diferentes partidos de centro pudieran de-

\footnotetext{
68 Diariol6, 26-V-1983.

69 Cambiol6, 23-VI-1986.

70 Powell, 2002, p. 422.
} 
bilitarse compitiendo entre sí. En su opinión, eran Suárez y el CDS quienes poseían la legitimidad histórico-democrática del centro, y por tanto debía partir de ellos la iniciativa, pero el duque de Suárez rechazó en todo momento la unión. Esto llevó a que CEPA se disolviera y muchos de sus miembros ingresaran en el PRD, como García Díez, Arias-Salgado y Bustelo, críticos también con la ambigüedad adoptada por el CDS respecto a la OTAN ${ }^{71}$.

Ante la imposibilidad de alcanzar un acuerdo, el propio Roca lamentaba que

«No existe en este momento acuerdo alguno entre Suárez y yo o entre el reformismo y el CDS, entre otras razones porque Suárez no manifiesta ningún tipo de interés en ello. [...] Creo que ese acuerdo sería bueno y dimensionaría la opción de centro de una manera decisiva de cara a la política española [...] Si este acuerdo no se llega a hacer, yo no quiero aparecer ante la opinión pública como responsable. Y si el electorado decide castigar a alguien por no hacerlo, quiero que sepa a quien debe dirigirse ${ }^{72}$.

En el rechazo a la unión había cuestiones ideológicas, por ese tono popular del CDS que le distanciaba del PRD, y también razones personalistas, señalando algunos las duras exigencias realizadas por Suárez de cara a las posibles listas electorales ${ }^{73}$. Otros mencionan el peso ejercido por figuras como Eduard Punset, al frente del CDS en Cataluña, quien rechazaba desmantelar el grupo en favor de Convèrgencia tal y como deseaban los reformistas ${ }^{74}$. Al no ser posible la unión, se optó por tratar de desestabilizar la opción suarista. Florentino Pérez consiguió el apoyo de la CEOE y de Rafael Termes, presidente de la Asociación Española de Banca, para no financiar al CDS si concurría en solitario; mientras que el PRD recibiría altas aportaciones que se cifran desde los 5 mil a los 16 mil millones de pesetas. La presión financiera permitió un último intento por atraer al CDS a una coalición junto al PRD, celebrándose una reunión en marzo de 1986 entre Termes, Roca y Suárez, quien nuevamente se negó ${ }^{75}$. El CDS convocó entonces una reunión de su Comité Nacional, donde la

\footnotetext{
71 Quirosa-Cheyrouze, 2013,p. 413.

72 La Vanguardia, 4-V-1985.

73 Fuentes, 2011, p. 465.

74 Entrevista a Luis Marín, 14-XII-2017.

75 Morán, 2009, p. 574.
} 
mayor parte de la directiva, salvo Rafael Calvo y Chus Viana, se mostraron favorables a la unión con el PRD, ante lo cual Suárez anunció que dimitiría para no ser un obstáculo. Esto hizo que la cúpula del partido se retractase y aceptase finalmente la tesis suarista de concurrir en solitario ${ }^{76}$. Imposibilitada la unión de ambas formaciones, las tensiones fueron constantes, y si el PRD aseguraba que «alguien que evita la unión del centro es un apéndice del PSOE» ${ }^{77}$, desde las filas suaristas consideraban el PRD un «centrismo de laboratorio»o «un producto de marketing político» ${ }^{78}$.

Si el PRD fue visto como un enemigo por el otro gran partido de centro, el temor surgió igualmente en la derecha aunque, desde Coalición Popular, el nacimiento del PRD fue recibido de formas diversas: el PDP mantuvo una ambigua complicidad ante la aparición de un partido que aspiraba a articularse como alternativa de centro; los liberales de UL mantuvieron una constante pugna con el PRD, especialmente por la homologación exclusiva de este último en la Internacional Liberal; y desde AP hubo un «hostigamiento sin cuartel», aunque se producirían ciertas excepciones $^{79}$.

Cuando el PDP celebró su II Congreso en enero de 1985, Óscar Alzaga no dudó en apelar a la unión de las fuerzas antisocialistas y a la búsqueda de un espacio de centro, y es que los democristianos se sentían más cerca del programa del PRD que del neoliberalismo de Pedro Schwartz ${ }^{80}$. El PDP siempre había vivido su unión a Fraga con ciertos reparos, tratando de desmarcarse del carácter conservador de los aliancistas ${ }^{81}$. Vertebrada una alternativa de centro, Alzaga temía quedarse fuera, por lo que hacía guiños constantes a esa posible unión. Esos deseos fueron especialmente relevantes en Cataluña dada la buena relación de Juan José Folchi, al frente del PDP catalán, con la Unió Democràtica de Catalunya, el brazo democristiano de CiU. En marzo de 1985, Roca y Alzaga tuvieron un encuentro en casa de Florentino Pérez para tratar la posible unión de ambas formaciones ante las elecciones gallegas que se celebrarían ese año, pero por el momento la unión parecía difícil. Miembros destacados del PDP como José Manuel Otero Novas o José María Álvarez del Man-

\footnotetext{
76 Herrero, 2011, p. 249.

77 El Correo de Andalucía, 4-IV-1986.

78 El País, 28-I-1985.

79 Jáuregui, 2004, p. 184.

80 Penella, 2005, p. 778.

81 El País, 12-III-1985.
} 
zano eran abiertamente contrarios al abandono de Fraga y ruptura del pacto firmado ${ }^{82}$. Pero desde el mundo financiero y empresarial esa posible unión era bien contemplada y, finalmente, Carlos March logró arrancar el acuerdo de Alzaga para que, dadas las dificultades de romper la Coalición Popular, fuera después de los comicios cuando se integrara en un bloque reformista cuya importancia pronosticaban importante. Así se lo habría manifestado el propio Alzaga a compañeros del partido en una cena poco antes de las elecciones generales de $1986^{83}$.

Desde el brazo liberal de Coalición Popular, el nacimiento del PRD fue visto con ciertos recelos, especialmente en lo referido al reconocimiento de la Internacional Liberal, monopolizada por Garrigues. El propio Fraga, «padrino» de la UL, celebró una reunión con el Presidente de la Internacional Liberal, Malagodi, para obtener su apoyo, pero no lo consiguió ${ }^{84}$. Entonces Fraga decidió convertir la UL en un auténtico partido que, como señalaba Jorge Vertrynge, «fuera consistente y no el chiringuito del infeliz Pedro Schwarz ${ }^{85}$. Fraga logró, en primer lugar, atraer la Mesa Liberal, un pequeño grupo encabezado por Antonio Fontán, quien pasó a presidir la UL. Posteriormente, Fraga incorporó a José Antonio Segurado, presidente de la patronal madrileña, con quien perseguía conseguir una relación más igualitaria con la CEOE. Con la llegada de Segurado, la Unión Liberal se transformó en el Partido Liberal, que más allá de su apuesta por el liberalismo económico, en el resto de los aspectos seguía manteniendo un carácter profundamente conservador. Tampoco alcanzó este partido un mayor apoyo internacional, aunque a su acto de refundación acudieron figuras como William Roth, del Partido Republicano de Reagan, o Louis Michel, presidente del Partido Liberal belga.

Desde Alianza Popular, la Operación Roca fue duramente criticada al poner en duda el liderazgo de Fraga, quien calificó la operación de «puro sucursalismo catalán». También Miguel Herrero de Miñón lamentaba que «se desviaran hacia una operación estéril personas, recursos y apoyos que debieran haber nutrido y renovado la opción popular» ${ }^{86}$. Frente a ese rechazo generalizado, en las filas aliancistas surgió la voz discrepante de Alfonso Osorio, con gran prestigio dado su pasado como Vicepresidente

\footnotetext{
82 Entrevista a José Manuel Otero Novas, 13-III-2017.

83 Entrevista a José Manuel Otero Novas, 13-III-2017.

${ }^{84}$ Fraga, 1987, p. 332.

85 Verstrynge, 1999, p. 185.

${ }^{86}$ Herrero de Miñón, 1993, p. 317.
} 
de Suárez. Además, Osorio era el hombre de AP para las relaciones con la banca, vinculado personalmente a Banesto, amigo íntimo de Emilio Botín, y primo de Julio Arce, director del Banco de Vizcaya. Estas relaciones, unido a sus constantes deseos de colaboración de todo el centro-derecha, permiten entender la conferencia pronunciada por Osorio en enero de 1985 en el Club Siglo XXI. El santanderino aseguraba:

«Convergència i Unió, sin renunciar a ninguno de sus ideales catalanes, ha dejado de tener la espalda vuelta al resto de España; vuelve, como en la época de Cambó a interesarse seriamente por la política nacional. Este hecho, mal que les pese a algunos, supone crear posibilidades de entendimiento, $[\ldots]$ hoy se dan todas las condiciones objetivas para poder proponer a los españoles no socialistas algo que es inevitable en el futuro: un gobierno de coalición o una coalición para el gobierno [...] No se trata, en fin, de hacer un bloque férreamente unitario en el que unos partidos fagociten a otros, en el que unos satelicen a otros, se trata, por el contrario, [...] de encontrar un punto de conjunción, un punto de síntesis, un entendimiento lógico, una oferta equilibrada.» ${ }^{87}$

Lo que venía a manifestar Osorio era la necesidad de unir las fuerzas antisocialistas en un programa común, y consideraba que AP debía rehusar su lucha contra el PRD, y contra CiU en Cataluña, para sumarlos al proyecto común de apartar al PSOE del poder ${ }^{88}$. Osorio apuntaba que AP debía renunciar a cuatro elementos: la idea de mayoría natural, la búsqueda del bipartidismo perfecto, la unión de la derecha sólo a través de Coalición Popular, y el liderazgo de una sola persona, señalando que una cosa era el liderazgo de Fraga en AP, y otra el del centro-derecha ${ }^{89}$. Su idea fue abiertamente rechazada por la militancia aliancista, y desde la ejecutiva del partido se realizaron duras críticas contra Osorio, especialmente por parte de Jorge Fernández Díaz, al frente de AP en Cataluña. Tampoco Roca y los reformistas parecían dispuestos a alinearse con Fraga, por lo que su idea no tuvo mayor continuidad.

Este convulso escenario que se había abierto en el centro y centro-derecha con la aparición del PRD, tendría ocasión de experimentar sus primeros efectos con motivo de las elecciones gallegas del 24 de noviembre de 1985. El reformismo había depositado sus esperanzas en Coalición

\footnotetext{
87 Osorio, 1985, pp. 235-236.

88 Entrevista a Alfonso Osorio, 6-V-2016.

89 Osorio, 1985.
} 
Galega, partido que representaba a la operación en Galicia. Al frente de la candidatura, Roca y Pujol colocaron a Víctor Moro, Presidente del Banco de España en Barcelona y antiguo miembro de UCD, que sustituyó al hasta entonces líder galleguista Eulogio Gómez Franquiera, quien había sufrido un derrame cerebral. AP mostró sus preocupaciones porque Coalición Galega capitalizase el antiguo voto centrista y por los contactos que desde esta formación estaban manteniendo con el vicepresidente de la Xunta, José Luis Barreiro, y especialmente con Enrique Marfany, líder del PDP gallego ${ }^{90}$. En estas circunstancias, AP puso sus esfuerzos en dividir Coalición Galega, atrayendo a Victorino Nuñez, presidente de la Diputación de Orense, quien abandonó a los reformistas y fundó Centristas de Galicia, llevando hacia Coalición Popular a los alcaldes y concejales de los principales pueblos de la provincia ${ }^{91}$. La crisis de Coalición Galega causó la caída de Moro, quien fue reemplazado por Pablo González Mariñas. El PRD temía que los problemas sufridos por la formación gallega acabasen afectando al proyecto nacional, ya que las encuestas pronosticaban tan solo en torno a un $7 \%$ del voto, muy alejado del $27,8 \%$ de los votos obtenidos por UCD en 1981 que aspiraban a recoger. Su crisis había derivado también en un crecimiento del CDS en las encuestas gallegas, mientras Fraga se marcaba públicamente el objetivo de la mayoría absoluta despreciando la opción reformista. Finalmente, Coalición Galega consiguió un $12,9 \%$ de los votos y 11 diputados, lo que la convertía en la vencedora moral al ser la llave del gobierno autonómico. Frente a ellos, el CDS apenas obtuvo un 3,3\%, claramente superado por la opción reformista. Coalición Popular, clara vencedora de las elecciones, no había obtenido en cambio la mayoría absoluta que Fraga se había automarcado, por lo que decepcionado con el resultado presentó su dimisión como presidente de AP. Fraga consideraba que esa derrota moral afectaba no solo a «los grandes esfuerzos realizados en Galicia, sino que afecta a mi dignidad personal y a mi autoridad como presidente; así como a la credibilidad del partido» ${ }^{92}$. Rechazada por la ejecutiva aliancista, Fraga delegó de forma interina la presidencia de la formación, mostrando su pesimismo ante las expectativas reformistas que habían despertado los comicios gallegos.

$90 A B C, 22-\mathrm{I}-1985$.

91 Jáuregui, 2004, p. 169.

92 Carta de Manuel Fraga a Alfonso Osorio, 14-X-1985: AAO (El Archivo Alfonso Osorio se encuentra sin clasificar, lo que impide incluir su referencia). 
Galicia había demostrado que existía espacio para el centro y todo hacía presagiar que ese espacio sería capitalizado por el reformismo dado los malos resultados del CDS. Sin embargo, en dichas elecciones el CDS había presentado a un completo desconocido, José Otero, mientras que la formación reformista se había beneficiado de gran parte de las redes de lealtad caciquil que había logrado atraer. No obstante, hasta ese momento habían concurrido a las elecciones partidos vinculados a la operación reformista, pero no las federaciones regionales del PRD. Serían las elecciones andaluzas, convocadas para el 22 de junio de 1986, las primeras en poner a prueba al PRD.

\section{Las elecciones de 1986: el fin de un proyecto}

Luis Marín fue el candidato reformista para las elecciones andaluzas. El PRD se lanzaba con grandes expectativas a dichos comicios, pues el propio presidente de Andalucía, José Rodríguez de la Borbolla, les había informado de encuestas internas que indicaban las posibilidades de una opción centrista en conseguir 15 o 16 diputados $^{93}$. Los reformistas se acercaban a su prueba de fuego esperanzados en el resultado, un paso fundamental para asentar el partido en su expansión nacional. Hasta el momento, el reformismo contaba con diputados en cinco parlamentos autonómicos (Cataluña, Canarias, Baleares, Castilla y León, y Galicia), pero en ninguno con su propio nombre al ser diputados conseguidos por los partidos regionales o heredados del antiguo PDL de Garrigues. La sensación general en las filas reformistas era que se confirmaría un buen resultado similar al gallego. El PRD no contaba con un giro político del último momento. Felipe González, al sentirse respaldado por la victoria obtenida en el referéndum de la OTAN, adelantó las elecciones generales al 22 de junio, misma fecha que los comicios andaluces. Con este adelanto electoral, el reformismo no podría hacer bandera de las demandas regionales como clave de su progresivo proyecto de expansión nacional, y hubo de lanzarse a unas elecciones generales en las que competir contra González, Suárez y Fraga, quien había retomado la presidencia de AP.

$\mathrm{Si}$ el adelanto electoral dificultaba su proyecto, la decisión final de Roca de concurrir por Barcelona, reafirmando su vinculación a la política

93 Entrevista a Luis Marín, 14-X-2017. 
catalana, otorgó a sus contrincantes la baza perfecta para criticar a los reformistas y considerarlos un mero proyecto catalanista. Esta imagen fue reafirmada desde la propia televisión pública, donde a pesar de la participación de Roca en diversos mítines por toda España, las imágenes utilizadas fueron siempre de actos en Cataluña, con intervenciones de Roca en catalán subtituladas al castellano ${ }^{94}$. Desde el reformismo siempre se responsabilizó a los socialistas, y concretamente a Alfonso Guerra, de estas operaciones en la televisión pública, y aunque ciertamente los socialistas no temían al reformismo del modo que lo podían hacer Suárez o Fraga, sí trataron de limitar los efectos de la operación enfatizando su carácter catalanista. En estas circunstancias, el propio Pujol sugirió a Roca «que trasladase su residencia a Madrid y que dirigiese desde allí el partido», pero este se negó ${ }^{95}$. Roca insistía en su posibilidad de concurrir a la presidencia desde Barcelona, explicando cómo Bettino Craxi había sido candidato en Italia presentándose por Milán, pero sus argumentos no surtirían efecto. Su actitud tampoco ayudó a borrar esa imagen, y es que su obsesión por conseguir que CiU derrotara en Cataluña al PSC le llevó a, en alguna ocasión, abandonar la caravana del PRD para participar en actos celebrados en Cataluña ${ }^{96}$. De este modo, la imagen de candidatura catalana del reformismo se fue asentado, e incluso en Andalucía, en las caricaturas realizadas sobre los candidatos regionales, Marín solía ser representado ataviado con una barretina ${ }^{97}$.

Este no fue el único problema de los reformistas. Si resultaba llamativo que su candidato a la presidencia no encabezase la candidatura madrileña, aún más sorprendente fue que tampoco lo hiciera el presidente del partido. Garrigues fue relegado al segundo puesto, pues amplios sectores del PRD lo contemplaban como una especie de «Lola Flores del reformismo» ${ }^{98}$. Como aficionado al teatro, Garrigues solía rodearse de actores y actrices con los que representaba en su casa obras escritas por él mismo, afición que los sectores más puritanos del reformismo consideraban excéntrica. En su lugar, el PRD puso al frente de la candidatura madrileña a Federico Carlos Sainz Robles, antiguo Presidente del Tribunal Supremo cuyo prestigio esperaban diera resultados. Esta se trató de una extraña decisión, abandonándose la explotación de «un líder muy vendible» para

\footnotetext{
94 Cambiol6, 23-VI-1986.

95 Pujol, 2009, p. 151.

96 ABC, 2-VI-1986.

97 Memorias inéditas de Luis Marín Sicilia.

98 Tiempo, 17-II-1986.
} 
apostar por una figura como Sainz Robles, que ni siquiera militaba en el partido y se presentaba como independiente ${ }^{99}$. La situación se complicó aún más con la actitud adoptada por este durante la campaña, que rehuyó de las fórmulas más tópicas de visitas a mercadillos, mítines o caravanas, y apostó por diálogos y debates en pequeños auditorios.

Pese a todo, los reformistas se lanzaron esperanzados a la campaña bajo el eslogan «Hay otra forma de hacer España», y el propio Roca declaró que «recogeremos la bandera del cambio que los socialistas se dejaron olvidada» ${ }^{100}$. Pero las encuestas comenzaban a pronosticar el hundimiento de la alternativa que tantas esperanzas había despertado, augurándose en torno a un 5-6\%, frente a un CDS que se situaba por delante como clara vencedora en la competición por el centro. Desde el reformismo Roca trató de quitar valor a los sondeos, mientras que Pujol no dudaba en insinuar la actuación directa del gobierno sobre unas encuestas que tratarían de inflar a Suárez para así dirigir al electorado centrista hacia una opción con menos riesgos para los intereses socialistas ${ }^{101}$. Pero el temor a ese fracaso se empezaba a sentir entre los diversos sectores de la banca y el mundo empresarial que habían financiado la Operación Reformista. Cuevas se reunió con Roca para pedirle que se retirasen de aquellas circunscripciones con 4 o menos diputados para no dividir el voto no socialista, pero Roca se negó. Alfonso Osorio, quien tiempo atrás había pedido la colaboración con los reformistas, escribió a Fraga para decirle que «más de un Presidente de Banco y más de un empresario me están insistiendo para que hable con Miguel Roca sobre la retirada de este en quince provincias tal y como le han indicado; y que lo haga con urgencia. Les he contestado que lo haré cuando tenga tu autorización» ${ }^{102}$. Pero los miedos que habían surgido en Fraga tras las elecciones gallegas ya habían desaparecido, y el dirigente aliancista no hizo nada confiado en el mínimo impacto que los reformistas tendrían en las urnas.

Cuando el 22 de junio se celebraron las elecciones, la candidatura reformista cosechó un rotundo fracaso. El PRD sólo consiguió 194.538 votos, lo que suponía un $0,96 \%$ de los votantes y ningún escaño. Por su parte, entre los partidos federados, Coalición Galega obtenía un diputado mientras CiU alcanzaba los 18 escaños, superando ampliamente sus re-

\footnotetext{
$99 \mathrm{Ya}, 14-\mathrm{VI}-1986$.

100 Diario16, 21-VI-1986.

101 Quirosa-Cheyrouze, 2016,p. 117.

102 Carta de Alfonso Osorio a Manuel Fraga, 19-V-1986: AAO.
} 
sultados de las anteriores elecciones y consiguiendo su mejor resultado hasta el momento, lo que evidenciaba cómo su proyección nacional la había permitido aumentar sus apoyos en Cataluña. Frente al fracaso del proyecto reformista, el CDS había logrado captar el voto de centro, con 1.861 .912 votos y 19 escaños. En las elecciones andaluzas, los resultados obtenidos por Luis Marín fueron igualmente insignificantes, con apenas un $0,78 \%$ de los votos.

\section{Cuadro 2}

Resultados de la Operación Reformista en las elecciones generales de 1986 por Comunidad Autónoma ${ }^{103}$

\begin{tabular}{lrcc}
\hline \multicolumn{1}{c}{ Comunidad } & \multicolumn{1}{c}{ Votos } & Porcentaje & Escaños \\
\hline Andalucía & 29.110 & $0,86 \%$ & 0 \\
Aragón & 7.370 & $1,11 \%$ & 0 \\
Asturias & 5.105 & $0,84 \%$ & 0 \\
Baleares & 24.379 & $7,15 \%$ & 0 \\
Canarias & 9.848 & $1,47 \%$ & 0 \\
Cantabria & 3.866 & $1,33 \%$ & 0 \\
Castilla-La Mancha & 8.887 & $0,93 \%$ & 0 \\
Castilla y León & 19.815 & $1,34 \%$ & 0 \\
Cataluña & $\mathbf{1 . 0 1 4 . 2 5 8}$ & $\mathbf{3 2 , 0 0 \%}$ & $\mathbf{1 8}$ \\
Comunidad Valenciana & 27.354 & $1,31 \%$ & 0 \\
Extremadura & 5.759 & $0,96 \%$ & 0 \\
Galicia & $\mathbf{7 9 . 9 7 2}$ & $\mathbf{6 , 2 4 \%}$ & $\mathbf{1}$ \\
La Rioja & 2.824 & $1,90 \%$ & 0 \\
Madrid & 36.709 & $1,42 \%$ & 0 \\
Murcia & 7.067 & $1,32 \%$ & 0 \\
Navarra & 5.481 & $2,01 \%$ & 0 \\
País Vasco & - & - & - \\
Ceuta & 499 & $2,06 \%$ & 0 \\
Melilla & 465 & $2,35 \%$ & 0 \\
\hline
\end{tabular}

Fuente: elaboraciónpropiaapartirdehttps:/www.20minutos.es/resultados-elecciones/1986/ congreso/ [Consulta realizada en abril de 2018].

103 Datos del PRD y, en los casos catalán y gallego, sus representantes en dichas comunidades (CiU y CG). Asimismo, en País Vasco no presentó candidatura. 
Tras el desastre electoral, los abandonos no tardaron en llegar, y pasado el verano Antonio Garrigues y Florentino Pérez dejaron el PRD. Tras su marcha se constituyó una Comisión Delegada, encabezada por Joaquín Satrústegui, encargada de organizar un Congreso Extraordinario en el primer trimestre de 1987 para reorganizar el partido. Pero las pocas esperanzas en el futuro de la formación acabaron suponiendo su disolución ${ }^{104}$. Las ilusiones puestas años atrás en construir una alternativa liberal con la que ocupar el centro había fracasado, emergiendo en su lugar un CDS de perfiles ideológicos más indefinidos. Con el tiempo, el propio Garrigues acabo abriéndolo las puertas de la Internacional Liberal, aunque él nunca llegaría a militar en el CDS ${ }^{105}$. La Operación Roca había naufragado. Reflexionando sobre el proyecto, Garrigues cree «que hicimos todo bien y que deberíamos haber tenido más éxito, pero yo lo que nunca voy a protestar es de los ciudadanos, un liberal no puede echar la culpa al ciudadano. Si el ciudadano no nos votó es porque no lo hicimos bien» ${ }^{106}$.

\section{A modo de conclusiones}

Constatado el fracaso de la Operación Roca, y a pesar de la confianza de sus miembros sobre las virtudes del proyecto, cabe preguntarse qué sucedió para que la alternativa representada por el Partido Reformista Democrático obtuviera tan bajos resultados. Vista la trayectoria seguida por la operación, así como las características e identidad que definieron a la formación liberal, podemos señalar diversas causas en dicho fracaso:

1. Un problema de liderazgo, ya que a pesar del prestigio que podía tener la figura de Miquel Roca, resultaba difícil de comprender para el electorado que el candidato presentado por el PRD, no sólo no militara en la formación por la que se presentaba, sino que además era miembro de otro partido, cuya actividad política se limitaba al ámbito catalán. Este problema en torno al liderazgo de Roca resultaba aún más conflictivo al haberse construido toda la operación en torno a su persona, no contando, o habiendo desplazado, a otros posibles líderes.

104 Entrevista a Luis Marín, 14-XII-2017.

105 ABC, 18-IX-1988.

106 Entrevista a Antonio Garrigues Walker, 27-IV-2017. 
2. La vinculación al nacionalismo catalán, certificada con la militancia de Roca en Convergència y su decisión de concurrir por Barcelona, algo que sus rivales supieron instrumentalizar en su beneficio. Aunque Convergència fuera la rama catalana del reformismo, esto resultaba difícil de comprender en el resto de España, y así como en Cataluña su proyección nacional sirvió para potenciar un crecimiento, en el resto de España fue visto como un intento del catalanismo por aumentar su influencia en la política nacional.

3. Un problema ideológico, ya que el PRD abrazó un discurso liberal-demócrata basado en una serie de reformas económico-administrativas que parecían dejar en segundo plano el discurso social que había caracterizado al proyecto radical diseñado inicialmente por Garrigues, lo que permitió que la bandera social del centro fuera monopolizada por Suárez. El reformismo adoptó un tono excesivamente academicista, y en cierto modo elitista, con el que parecía tratar de distanciarse del tono populista del CDS. Esto llevó incluso a que la búsqueda de una imagen de seriedad y gobernabilidad acabara distanciándolo de las clases populares y transmitiera la apariencia de «partido del poder», algo que pareció confirmar ante los ojos del electorado los importantes apoyos recibidos desde el mundo financiero y empresarial.

4. La estructura federal del partido, lo que hacía necesario una mínima vertebración territorial antes de lanzarse a unas elecciones generales. Precisamente fueron Convergència en Cataluña y Coalición Galega en Galicia, formaciones ya presentes en las asambleas regionales, las que obtuvieron unos mejores resultados. En este sentido, el adelanto electoral que impidió al reformismo asentarse en Andalucía y confirmar su proyección nacional, también pudo tener cierta influencia, aunque cabe dudar hasta qué punto dicha expansión hubiera sido suficiente.

Estas se tratan de algunas de las principales causas que impidieron la vertebración en España de una opción liberal de centro, triunfando en su lugar un CDS excesivamente vinculado a su líder, por lo que al abandonar Suárez la política, la formación no tardó en desaparecer. Finalizaban así los proyectos por articular en España un partido de centro, tardando varios años en volverse a intentar. 


\section{Fuentes}

Archivos

- Archivo Alfonso Osorio (Real Academia de Ciencias Morales y Políticas).

- Registro General de Partidos Políticos (Ministerio del Interior).

\section{Documentos}

- Memorias inéditas de Luis Marín Sicilia.

- PRD, Por fin la alternativa: proyecto de ponencias: Primer Congreso Federal, 23-24-25 de noviembre de 1984, Madrid, 1984.

- PRD, La alternativa reformista, Madrid, 1985.

- PRD, Pensamiento reformista, Madrid, 1985(b).

Prensa

$-A B C$ (Madrid).

- Cambio16 (Madrid).

- Correo de Andalucía, El (Sevilla).

- Diario16 (Madrid).

- País, El (Madrid).

- Tiempo (Madrid).

- Vanguardia, La (Barcelona).

- Voz de Córdoba, La (Córdoba).

- Ya (Madrid).

Entrevistas

- Alfonso Osorio, 6-V-2016.

- Antonio Garrigues Walker, 27-IV-2017.

- José Manuel Otero Novas, 13-III-2017.

- Luis Marín Sicilia, 14-XII-2017. 


\section{Bibliografía}

Alonso-Castrillo, Silvia, La apuesta del centro. Historia de la UCD, Alianza, Madrid, 1996.

CAldÉs, Juan Antonio y GARrigues WALKer, Antonio, La alternativa liberal, Argos Vergara, Barcelona, 1983.

Calvo-Sotelo, Leopoldo, Memoria viva de la Transición, Plaza y Janés, Barcelona, 1990.

DíEz, Darío, Adolfo Suárez y el Centro Democrático y Social (1982-1991). Tesis doctoral inédita, Universidad de Valladolid, 2017.

FraGa, Manuel, En busca del tiempo servido, Planeta, Barcelona, 1987.

Fuentes, Juan Francisco, Adolfo Suárez, Planeta, Barcelona, 2011.

García-León, Carlos y Martínez-Echevarría, Borja, Antonio Garrigues Walker, Península, Barcelona, 2014.

GonZÁlez, Pedro Carlos, Historia de las derechas españolas, Biblioteca Nueva, Madrid, 2000.

GUNTHER, Richard, «El hundimiento de UCD», en LinZ, Juan José y MoNTERo, José Ramón, Crisis y cambio: electores y partidos en la España de los años ochenta, Centro de Estudios Constitucionales, Madrid, 1986, pp. 433-492.

Herrero, Luis, Los que le llamábamos Adolfo, La Esfera de los Libros, Madrid, 2007.

Herrero de Miñón, Miguel, Memorias de estío, Temas de hoy, Madrid, 1993.

HuneEus, Carlos, La Unión de Centro Democrático y la transición a la democracia en España, Siglo XXI, Madrid, 1985.

JÁuREgui, Fernando, La derecha después de Fraga, El País, Madrid, 1987.

JÁuregui, Fernando, Cinco horas y toda una vida con Fraga, Espejo de Tinta, Madrid, 2004.

MonTERo, José Ramón, «El sub-triunfo de la derecha: los apoyos electorales de AP-PDP», en Linz, Juan José y MonTERo, José Ramón, Crisis y cambio: electores y partidos en la España de los años ochenta, Centro de Estudios Constitucionales, Madrid, 1986, pp. 345-432.

Morán, Gregorio, Adolfo Suárez. Ambición y destino, Planeta, Barcelona, 2009.

Osorio, Alfonso, Escrito desde la derecha, Plaza y Janés, Barcelona, 1985.

PAPEll, Antonio, Conversaciones con Miquel Roca Junyent, Argos Vergara, Barcelona, 1984.

Penella, Manuel, Los orígenes y la evolución del Partido Popular. Tomo II: 1982-1989, Caja Duero, Salamanca, 2005.

Pi, Ramón, Joaquín Garrigues Walker, Unión Editorial, Madrid, 1979.

Powell, Charles, España en democracia, 1975-2000, DeBolsillo, Barcelona, 2002.

Powell, Charles, «El principal partido de la oposición y el «gobierno largo» del PSOE: de Fraga a Aznar», en SOTO, Álvaro y MATEOS, Abdón, Historia de la época socialista, Sílex, Madrid, 2013, pp. 389-404. 
Pujol, Jordi, Tiempo de construir, Destino, Barcelona, 2009.

Quirosa-Cheyrouze, Rafael, «El Centro Democrático y Social. Auge y caída de un proyecto político (1982-1996)», en Soto, Álvaro y MATEOs, Abdón, Historia de la época socialista, Sílex, Madrid, 2013, pp. 405-430.

Quirosa-Cheyrouze, Rafael, «El resurgir de Adolfo Suárez. Las elecciones de 1986 y el Centro Democrático y Social», en Historia del Presente, 28, 2016, pp. 114-130.

RocA, Miguel, Per qué no?, Portic, Barcelona, 1982.

Verstrynge, Jorge, Memorias de un maldito, Grijalbo, Barcelona, 1999.

VV.AA., España hoy, Unión Editorial, Madrid, 1984.

\section{Financiación y agradecimientos}

Este trabajo se enmarca en el proyecto financiado por la Agencia Estatal de Investigación y por el Fondo Europeo de Desarrollo Regional: «La razón biográfica: biografías y narraciones autobiográficas en la investigación histórica y literaria del siglo XX europeo. Estudios de caso y reflexión teórica». HAR2017-82500-P (AEI/ FEDER/ UE).

El autor desea mostrar su agradecimiento a las personas que, a través de su testimonio y la aportación de fuentes inéditas, facilitaron la realización de esta investigación.

\section{Datos del autor}

Adrián Magaldi Fernández es graduado en Historia por la Universidad de Cantabria, con Máster Interuniversitario en Historia Contemporánea cursado en la Universidad de Cantabria, Universidad Autónoma de Madrid y Universidad Complutense de Madrid. En la actualidad, contratado predoctoral de la Universidad de Cantabria realizando la tesis doctoral "Alfonso Osorio. Una biografía política». 